\title{
lonized Magnesium and Regional Citrate Anticoagulation for Continuous Renal Replacement Therapy
}

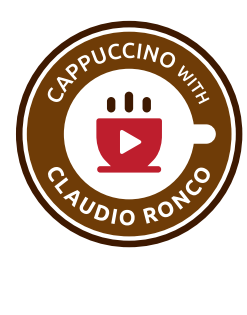

\author{
Mychajlo Zakharchenko ${ }^{a}$ Pavel Leden ${ }^{a}$ Jan Rulíšek ${ }^{a}$ Ferdinand Los ${ }^{b}$ \\ Helena Brodska ${ }^{b}$ Martin Balik ${ }^{a}$ \\ a Department of Anesthesiology and Intensive Care and ${ }^{b}$ Department of Clinical Biochemistry, First Faculty of \\ Medicine, Charles University and General University Hospital in Prague, Prague, Czech Republic
}

\section{Key Words}

Magnesium · lonized magnesium · Magnesium deficiency ·

Calcium $\cdot$ Renal replacement therapy $\cdot$ Regional citrate anticoagulation

\section{Abstract \\ Background: The regional citrate anticoagulation (RCA) in- duces changes in total $\left(\mathrm{Ca}^{\text {tot }}\right)$ and ionized $\left(\mathrm{Ca}^{2+}\right)$ calcium. As of now, we do not have much information about parallel changes of total $\left(\mathrm{Mg}^{\text {tot }}\right)$ and ionized $\left(\mathrm{Mg}^{2+}\right)$ magnesium. Methods: The authors compared changes of $\mathrm{Mg}^{2+}$ and $\mathrm{Mg}^{\text {tot }}$ with changes of $\mathrm{Ca}^{2+}$ and $\mathrm{Ca}^{\text {tot }}$ in 32 critically ill patients on $4 \%$ trisodium citrate (4\% TSC) with calcium-free fluids. $\boldsymbol{R e}$ - sults: The median continuous venovenous hemodiafiltra- tion balance of $\mathrm{Mg}^{\text {tot }}$ was -0.91 ( -1.18 to -0.53$) \mathrm{mmol} / \mathrm{h} \mathrm{com}$ - pared to the median balance of $C \mathrm{C}^{\text {tot }} 0.86(0.08-1.55) \mathrm{mmol} / \mathrm{h}$. Postfilter $\mathrm{Mg}^{2+}$ decreased by $68.3 \%$ (70.8-65.6) in parallel $(\mathrm{r}=$ $0.41, \mathrm{p}=0.03$ ) to decrease of postfilter $\mathrm{Ca}^{2+}$ (by $70.2 \%$ (73.0- $66.1))$ and was significantly related to the postfilter $\mathrm{Ca}^{2+}(\mathrm{r}=$ $0.50, p<0.001)$. The decrease of prefilter to postfilter $\mathrm{Ca}^{2+}$ correlated to a dosage of $4 \%$ TSC per blood flow $(r=0.37, p=$ 0.04). Conclusions: The loss of $\mathrm{Mg}^{\text {tot }}$ during RCA is not cov- ered by magnesium concentration in ordinary dialysis/sub-}

stitution fluid and may lead to the depletion of total body magnesium. The postfilter $\mathrm{Mg}^{2+}$ is significantly related to the postfilter $\mathrm{Ca}^{2+}$.

Video Journal Club "Cappuccino with Claudio Ronco" at http://www.karger.com/?doi = 440972. 2015 s. Karger AG, Basel

\section{Introduction}

The efficacy and safety of regional citrate anticoagulation (RCA) have been reflected in guidelines, suggesting the use of citrate for prevention of filter clotting in preference to standard heparin even in patients without an increased bleeding risk [1-6]. Citrate inhibits coagulation through the chelation of ionized calcium $\left(\mathrm{Ca}^{2+}\right)$, which is the principle of all citrate modes of regional anticoagulation. The postfilter changes of $\mathrm{Ca}^{2+}$ are used to guide the dose of citrate, and substitution of calcium is required to maintain the systemic level of $\mathrm{Ca}^{2+}$.

Various citrate protocols have shown mild accumulation, deficit or even balance of total calcium $\left(\mathrm{Ca}^{\mathrm{tot}}\right)$, mostly depending on the intensity of calcium substitution [710]. Another bivalent cation likely to be chelated in a sim-

\section{KARGER}

E-Mail karger@karger.com

www.karger.com/bpu (c) 2015 S. Karger AG, Basel

0253-5068/15/0413-0041\$39.50/0
Martin Balik

Department of Anesthesiology and Intensive Care, First Faculty of Medicine Charles University and General University Hospital

U nemocnice 2, Prague 2, 12000 (Czech Republic)

E-Mailmartin.balik@vfn.cz 
Fig. 1. Configuration of the CVVHDF circuit under citrate anticoagulation. UF $=$ Ultrafiltration, that is, net fluid removal $(\mathrm{l} / \mathrm{h}) ; \mathrm{Qb}=$ blood flow $(\mathrm{l} / \mathrm{h}) ; \mathrm{Qc}=4 \%$ TSC flow $(\mathrm{l} / \mathrm{h})$; $\mathrm{Qd}=$ dialysis flow $(\mathrm{l} / \mathrm{h})$; Qeff = effluent flow $(\mathrm{l} / \mathrm{h})=\mathrm{UF}+\mathrm{Qc}+\mathrm{Qd}+$ postdilution.

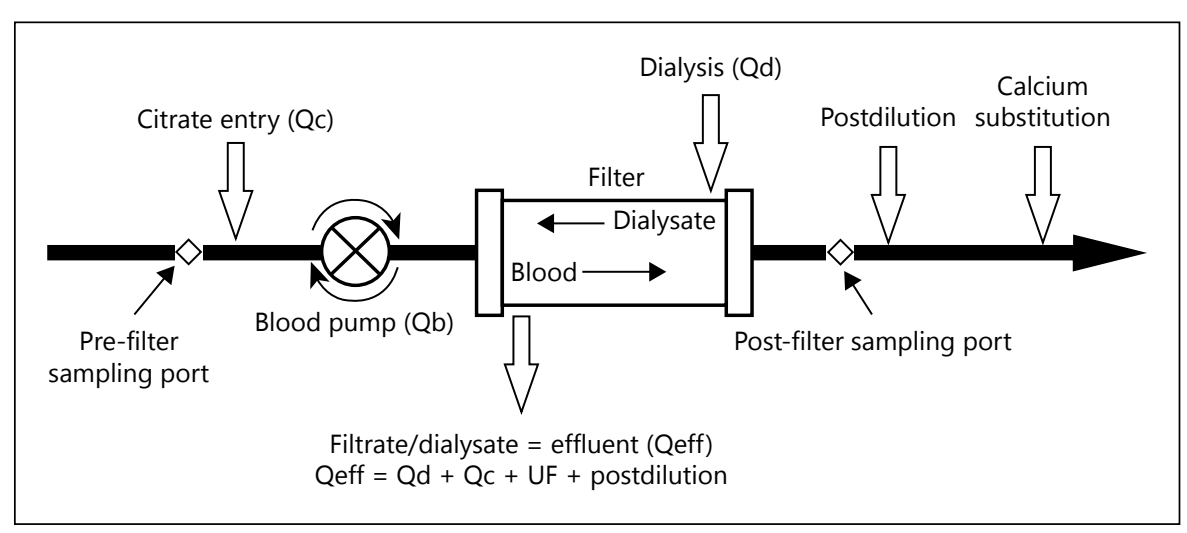

ilar fashion as calcium is magnesium. The balance of total magnesium $\left(\mathrm{Mg}^{\text {tot }}\right)$ is not well explored under various modalities and solutions used with citrate anticoagulation [11]. Brain found a significantly negative magnesium balance using dialysis/replacement fluids containing 0.5 $\mathrm{mmol} \mathrm{Mg}{ }^{\text {tot }}$ per liter [12]. While balances in total cations $\left(\mathrm{Ca}^{\text {tot }}\right.$ and $\left.\mathrm{Mg}^{\text {tot }}\right)$ have implications for total body pools and substitutions during RCA, the changes in ionized forms $\left(\mathrm{Ca}^{2+}\right.$ and $\left.\mathrm{Mg}^{2+}\right)$ represent changes of physiologic function (anticoagulation) and are included in the balances of the total ions. In contrast to $\mathrm{Ca}^{2+}$, the ionized magnesium $\left(\mathrm{Mg}^{2+}\right)$ is not monitored as part of citrate modality of continuous renal replacement therapy (CRRT); yet, its decrease is directly related to patient's prognosis [13]. Besides a single paper on $\mathrm{Mg}^{2+}$ changes during platelet apheresis [14], the exact relationship of $\mathrm{Ca}^{2+}$ to changes of $\mathrm{Mg}^{2+}$ under citrate anticoagulation that are not monitored in renal failure patients is not known. The aims of the study were to determine whether the postfilter $\mathrm{Mg}^{2+}$ is related to postfilter $\mathrm{Ca}^{2+}$ and whether the decrease in postfilter $\mathrm{Mg}^{2+}$ is related to the decrease in postfilter $\mathrm{Ca}^{2+}$. RCA might cause a magnesium loss on filter similar to loss of calcium. Magnesium depletion potentiated by citrate may not be compensated by current levels of magnesium in dialysis and substitution fluid.

\section{Methods}

This prospective observational study was carried out in a 20 bed ICU of the university hospital. The study was approved by the university hospital ethical board and informed consent was obtained from the next of kin. All patients were critically ill and mechanically ventilated.

The fluxes of magnesium and calcium, changes of their ionized forms and possible relationships to citrate dosage and citratemias were studied during postdilution continuous venovenous hemo- diafiltration (CVVHDF) performed on Aquarius device (Baxter ${ }^{\circledR}$, Irvine, Calif., USA) with $1.9 \mathrm{~m}^{2}$ polysulfone filter (Aquamax ${ }^{\circledR}$, Bellco, Mirandola, Italy). The commercially available trisodium citrate (4\% TSC) and dialysis/substitution fluid were used. The bicarbonate buffered solution was calcium-free and had reduced levels of sodium and bicarbonate. The fluid was used as dialysis and replacement fluid (Citralysate ${ }^{\circledR}$, GML, Czech Republic, Na 133 $\mathrm{mmol} / \mathrm{l}, \mathrm{K} 2.0 \mathrm{mmol} / \mathrm{l}, \mathrm{Mg} 0.75 \mathrm{mmol} / \mathrm{l}, \mathrm{Cl} 116.5 \mathrm{mmol} / \mathrm{l}$, glucose $\left.5.6 \mathrm{mmol} / \mathrm{l}, \mathrm{HCO}_{3}{ }^{-} 20 \mathrm{mmol} / \mathrm{l}\right)$.

Indications for RRT were renal failure with elevated levels of uremic toxins and loss of response to diuretics. Prescribed CVVHDF dose was $20-25 \mathrm{ml} / \mathrm{kg} / \mathrm{h}[15,16]$. The dialysis flow (Qd) was set at $1,500 \mathrm{ml} / \mathrm{h}$ and postdilution at $500 \mathrm{ml} / \mathrm{h}$. The blood flow $(\mathrm{Qb})$ was set at $100 \mathrm{ml} / \mathrm{min}$. Reason to use a lower $\mathrm{Qb}$ was to allow for a lower citrate flow, which prevents metabolic alkalosis and hypernatremia $[17,18]$. A Qb of $100 \mathrm{ml} / \mathrm{min}$ is sufficient to saturate dialysate at a flow rate of $2 \mathrm{l} / \mathrm{h}$ [19]. Four percent TSC infusion was initiated at $200 \mathrm{ml} / \mathrm{h}$ and titrated in increments to maintain the postfilter $\mathrm{Ca}^{2+}$ under $0.4 \mathrm{mmol} / \mathrm{l} . \mathrm{Ca}^{2+}$ was checked every hour until its level became stable and thereafter once in every 3 hours. Calcium chloride (10\%) was infused into a port distal from the venous bubble trap to maintain arterial $\mathrm{Ca}^{2+}$ within a normal range $(0.8-1.3 \mathrm{mmol} / \mathrm{l})$. Arterial $\mathrm{Ca}^{2+}$ was monitored every $6 \mathrm{~h}$. A routine substitution of intravenous $20-30 \mathrm{ml}$ of $20 \%$ magnesium sulfate (16.2-24.3 mmol) per day was part of the RCA protocol.

The study commenced at least $24 \mathrm{~h}$ after the start of CRRT. Samples were drawn from the arterial blood, the effluent, the prefilter and postfilter ports of the circuit (fig. 1). To improve accuracy, the second sampling took place 60 min later. During this hour, the configuration of CRRT including anticoagulation did not change. $\mathrm{Ca}^{2+}$ and $\mathrm{Mg}^{2+}$ were measured using the STAT profile analyzer (Nova Biomedical) at the bedside. Besides measuring citrate levels (measured by capillary zone electrophoresis, P/ACE 5100 , Beckman), the laboratory analysis also included the measuring of $\mathrm{Ca}^{\text {tot }}$ and $\mathrm{Mg}^{\text {tot }}$.

\section{Calculation of Magnesium and Calcium Fluxes from Patient's} CVVHDF Circuit to the Effluent

The amount of magnesium removed on filter was deducted from magnesium delivered as part of dialysis fluid and postdilution. Effluent removal of magnesium was calculated from the effluent flow (Qeff) multiplied by the magnesium concentration in the effluent ([Mg]eff). Magnesium input was calculated as Qd
Zakharchenko/Leden/Rulíšek/Los/ Brodska/Balik 
Table 1. Levels of citrate, total and ionized cations in arterial blood, prefilter, postfilter and effluent samples

\begin{tabular}{lllllll}
\hline $\begin{array}{l}\text { Parameter, } \\
\text { mmol/l }\end{array}$ & Arterial & Prefilter & Postfilter & Change, mmol/l & Change, $\%$ & Effluent \\
\hline Citrataemia & $0.55(0.41$ to 0.75$)$ & $0.61(0.41$ to 0.92$)$ & $3.99(3.47$ to 5.11$)$ & $3.54(2.6$ to 4.5$)$ & $684(284.6$ to $1,140.5)$ & $5.9(5.31$ to 6.51$)$ \\
$\mathrm{Ca}^{\text {tot }}$ & $2.27(2.07$ to 2.47$)$ & $2.27(2.1$ to 2.41$)$ & $1.55(1.44$ to 1.79$)$ & $-0.63(-0.8$ to -0.52$)$ & $-43.6(-52.9$ to -29.7$)$ & $1.59(1.52$ to 1.71$)$ \\
$\mathrm{Ca}^{2+}$ & $1.07(0.99$ to 1.15$)$ & $1.02(0.96$ to 1.11$)$ & $0.32(0.27$ to 0.37$)$ & $-0.75(-0.78$ to -0.65$)$ & $-70.2(-73.0$ to -66.1$)$ & $0.30(0.25$ to 0.34$)$ \\
$\mathrm{Mg}^{\text {tot }}$ & $1.08(0.88$ to 1.26$)$ & $1.07(0.94$ to 1.23$)$ & $0.9(0.84$ to 1.09$)$ & $-0.12(-0.19$ to -0.06$)$ & $-11.0(-19.9$ to -7.9$)$ & $1.0(0.76$ to 1.18$)$ \\
$\mathrm{Mg}^{2+}$ & $0.51(0.43$ to 0.61$)$ & $0.46(0.40$ to 0.58$)$ & $0.15(0.13$ to 0.18$)$ & $-0.31(-0.4$ to -0.26$)$ & $-68.3(-70.8$ to -65.6$)$ & $0.14(0.12$ to 0.17$)$ \\
\hline
\end{tabular}

The changes are differences in concentrations during passage through blood circuit without including postfilter calcium substitution.

times magnesium concentration in the dialysis fluid ([Mg]d) plus postdilution flow times postdilution magnesium concentration ([Mg]d). The same fluid was used for dialysis and postdilution.

$$
\begin{aligned}
\text { Magnesium flux }= & (\mathrm{Qd} \times[\mathrm{Mg}] \mathrm{d}+\text { post-dilution } \times[\mathrm{Mg}] \mathrm{d})- \\
& \text { Qeff } \times[\mathrm{Mg}] \text { eff }
\end{aligned}
$$

The calcium flux was calculated similarly, that is, by deducting the calcium amount eliminated in the effluent from the calcium input. The effluent amount of calcium was calculated as Qeff multiplied by the effluent calcium concentration ([Ca]eff). Due to the fact that dialysate and postdilution calcium concentration ([Ca]d) equals zero, the calcium input was calculated as calcium replacement flow $(\mathrm{Q}[\mathrm{Ca}])$ times $10 \%$ calcium chloride concentration ([Ca $]$ in $=0.456 \mathrm{mmol} / \mathrm{ml}$ ). For better comparison to magnesium flux, the results were recorded as calcium balance without postfilter calcium substitution and overall calcium flux including postfilter $\mathrm{CaCl}_{2}$ infusion.

\section{Calcium flux $=\mathrm{Q}[\mathrm{Ca}] \times[\mathrm{Ca}]$ in - Qeff $\times[$ Ca $]$ eff}

The postfilter $\mathrm{Mg}^{2+}$ and postfilter $\mathrm{Ca}^{2+}$ were tested for correlations to prefilter levels. The postfilter $\mathrm{Mg}^{2+}$ levels were also tested for a relationship to postfilter $\mathrm{Ca}^{2+}$ levels. Changes of ionized cations in blood during passage through filter (i.e. absolute value of difference between prefilter and postfilter levels and the decrease of post to prefilter values in percent of prefilter values) were tested for correlations between $\mathrm{Mg}^{2+}$ and $\mathrm{Ca}^{2+}$. The decreases of both cations were tested for correlations with dosages of citrate, dosage of citrate per $\mathrm{Qb}$ and with changes of circuit citratemias (i.e. absolute value of difference between prefilter and postfilter levels of citrate).

The statistical analysis was performed using Statistica version 9 software. Data sets were checked for distribution, and the differences between groups were evaluated using the Mann-Whitney $\mathrm{U}$ test. Correlations between various parameters were tested using the Pearson's test. The level of significance was set at $\mathrm{p}=0.05$.

\section{Results}

A sequential sample of 32 patients was analyzed (age 67 (54.5-72.3), admission APACHE II 31 (27.5-37.3), SOFA $14(10-15))$.

$\mathrm{Mg}^{2+}$ and RCA

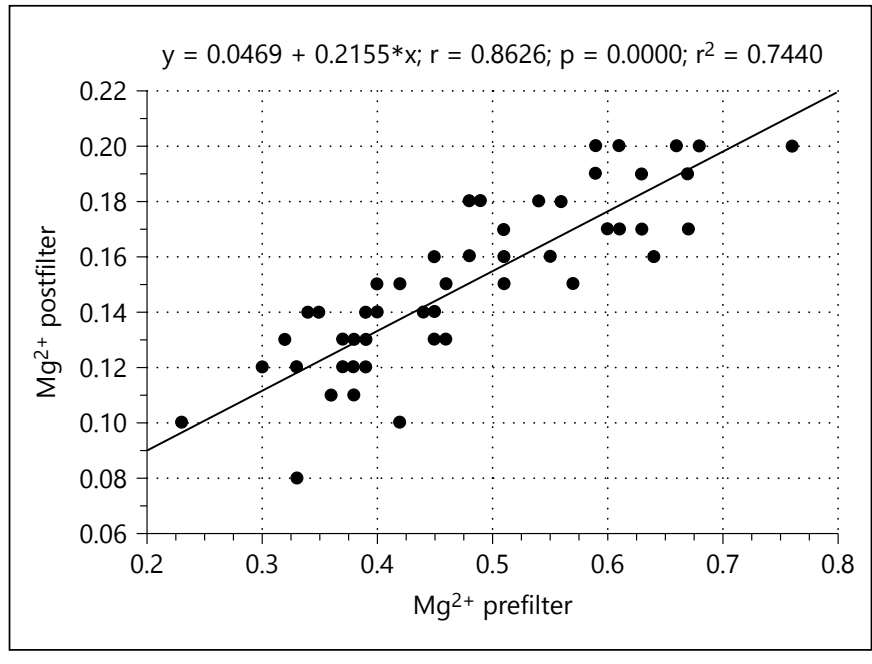

Fig. 2. The relationship of postfilter $\mathrm{Mg}^{2+}$ to prefilter $\mathrm{Mg}^{2+}(\mathrm{r}=$ $0.86, \mathrm{p}<0.001)$.

The median total Qeff was 2,370 $(2,290-2,420) \mathrm{ml} / \mathrm{h}$, citrate dose $200(180-230) \mathrm{ml} / \mathrm{h}$, that is, $26.5(24.5-32.6)$ $\mathrm{mmol} / \mathrm{h}$, citrate dose per Qb $4.4(4.1-5.4) \mathrm{mmol} / \mathrm{l} \cdot \mathrm{h}$. The median dosage of $10 \%$ postfilter calcium chloride was 9.5 $(8-12) \mathrm{ml} / \mathrm{h}$, that is, $4.3(3.7-5.5) \mathrm{mmol} / \mathrm{h}$. Ultrafiltration (net fluid loss) was titrated according to the hemodynamic needs. Median circuit survival time was 67 (44.5108) h.

The levels of citrate, total and ionized cations in arterial blood, prefilter, postfilter and effluent samples are shown in table 1 . The median balance of $\mathrm{Mg}^{\text {tot }}$ was -0.91 $(-1.18$ to -0.53$) \mathrm{mmol} / \mathrm{h}$ compared to the median balance of $\mathrm{Ca}^{\text {tot }}-3.80(-4.03$ to -3.5$) \mathrm{mmol} / \mathrm{h}$ without inclusion of postfilter $\mathrm{CaCl}_{2}$ substitution. The $\mathrm{Ca}^{\text {tot }}$ balance with input of postfilter calcium substitution was $0.86(0.08-$ $1.55) \mathrm{mmol} / \mathrm{h}$. The postfilter $\mathrm{Mg}^{2+}$ correlated to prefilter $\mathrm{Mg}^{2+}(\mathrm{r}=0.86, \mathrm{p}<0.001$; fig. 2$)$ similarly as did postfilter 


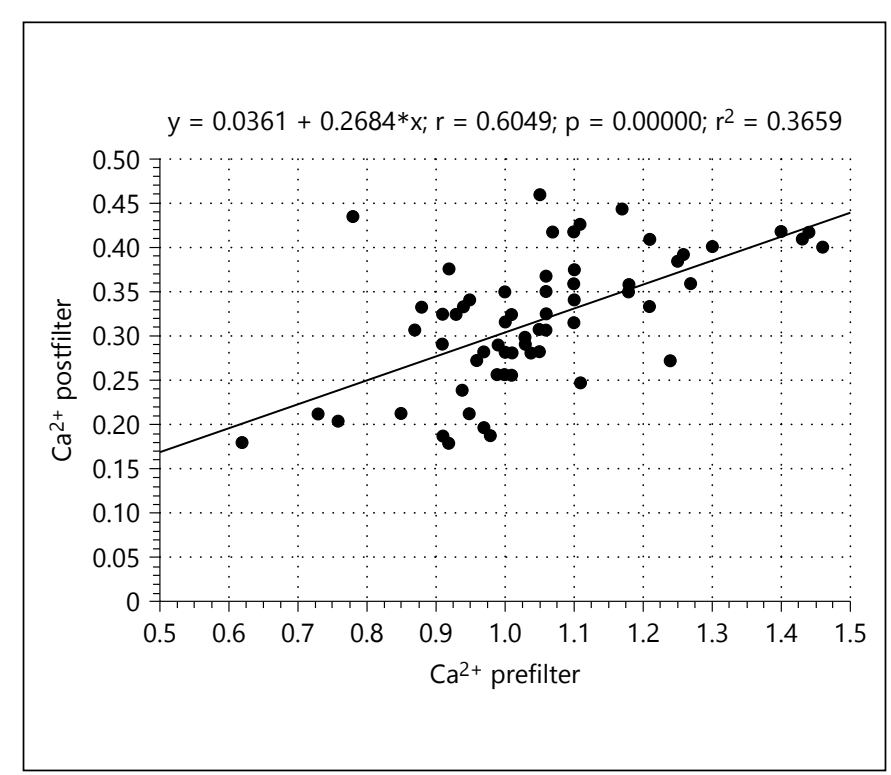

Fig. 3. The relationship of postfilter $\mathrm{Ca}^{2+}$ to prefilter $\mathrm{Ca}^{2+}(\mathrm{r}=0.60$, $\mathrm{p}<0.001)$.

$\mathrm{Ca}^{2+}$ to prefilter $\mathrm{Ca}^{2+}(\mathrm{r}=0.60, \mathrm{p}<0.001$; fig. 3$)$. In contrast to lack of significant relationship between prefilter $\mathrm{Mg}^{2+}$ to prefilter $\mathrm{Ca}^{2+}(\mathrm{r}=0.30, \mathrm{p}=0.13)$ the postfilter $\mathrm{Mg}^{2+}$ significantly correlated to postfilter $\mathrm{Ca}^{2+}(\mathrm{r}=0.50$, $\mathrm{p}<0.001$; fig. 4). The percentual decrease of $\mathrm{Mg}^{2+}(-68.3 \%$ $(-70.8$ to -65.6$))$ was significantly related to the percentual decrease of $\mathrm{Ca}^{2+}(-70.2 \%$ (-73.0 to -66.1$) ; \mathrm{r}=0.41$, $\mathrm{p}=0.03$; table 1 ; fig. 5 ). The relationships between absolute and percentual decreases of cations to dosages of citrate and circuit citratemias are summarized in table 2. The absolute and percentual decreases of prefilter to postfilter $\mathrm{Mg}^{2+}$ did not significantly correlate to absolute dose of citrate prefilter, dose of citrate per $\mathrm{Qb}$ or change of citrate levels. The absolute and percentual decreases of prefilter to postfilter $\mathrm{Ca}^{2+}$ did not significantly correlate to the absolute dose of citrate prefilter and to the change of citrataemia. The absolute decrease of $\mathrm{Ca}^{2+}$ correlated to the dose of citrate per $\mathrm{Qb}(\mathrm{r}=0.37, \mathrm{p}=0.04)$ as well as the percentual decrease of $\mathrm{Ca}^{2+} \operatorname{did}(\mathrm{r}=0.36, \mathrm{p}=0.04$; table 2).

\section{Discussion}

The present prospective observational cohort study, comparing the flux of magnesium with the flux of calcium during citrate-anticoagulated CVVHDF shows that the RCA associates with changes of magnesium

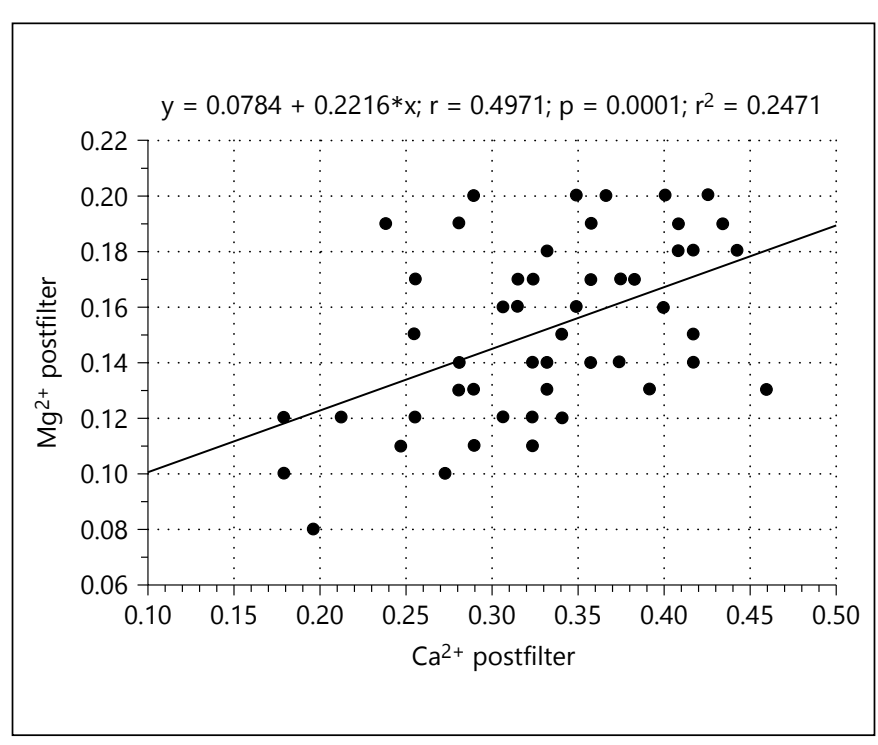

Fig. 4. The postfilter $\mathrm{Mg}^{2+}$ was significantly correlated to postfilter $\mathrm{Ca}^{2+}(\mathrm{r}=0.50, \mathrm{p}<0.001)$. Postfilter $\mathrm{Mg}^{2+}=0.08+0.22 \cdot$ postfilter $\mathrm{Ca}^{2+}$.

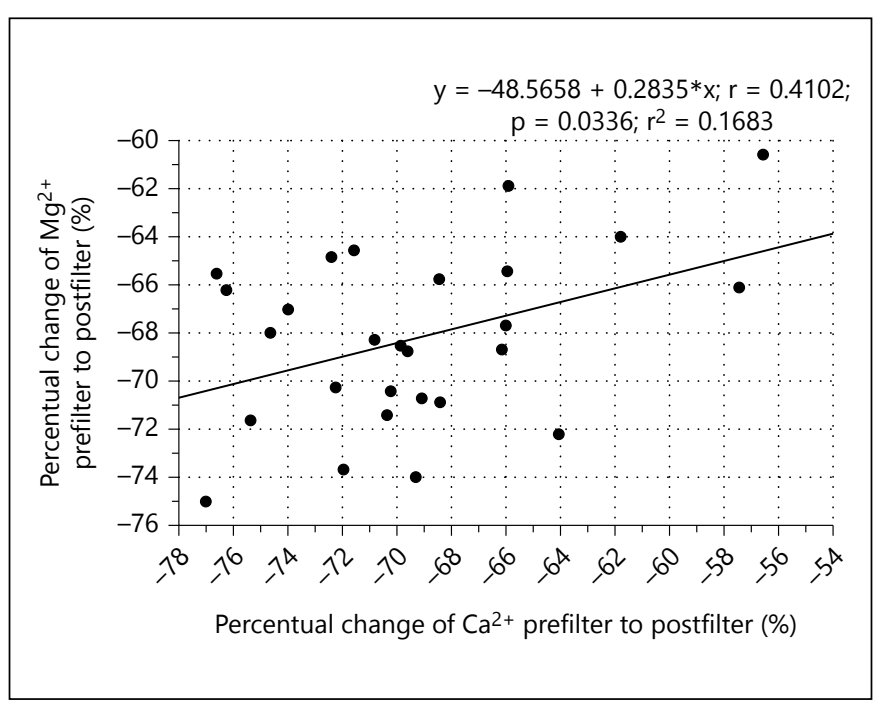

Fig. 5. The scatterplot of correlation between percentual decreases of $\mathrm{Mg}^{2+}$ and $\mathrm{Ca}^{2+}$ during passage through blood circuit under RCA $(\mathrm{r}=0.41, \mathrm{p}=0.03)$.

similar to changes of calcium. $\mathrm{Mg}^{2+}$ decreases to about one third during passage through citrate anticoagulated circuit, which is almost the same proportional decrease as for $\mathrm{Ca}^{2+}$. The effects of citrate upon ionized cations can also be seen by their correlation postfilter compared to relationship prefilter that is not significant. The measurement of $\mathrm{Mg}^{2+}$ is mostly unavailable; how-
44
Zakharchenko/Leden/Rulíšek/Los/ Brodska/Balik 
Table 2. The relationships (Pearson's correlation, the significant ones are in bold) between changes (absolute and percentual) in Ca ${ }^{2+}$, $\mathrm{Mg}^{2+}$ and dose of citrate prefilter, dose of citrate prefilter in relation to blood flow and increase of circuit citratemia during RCA

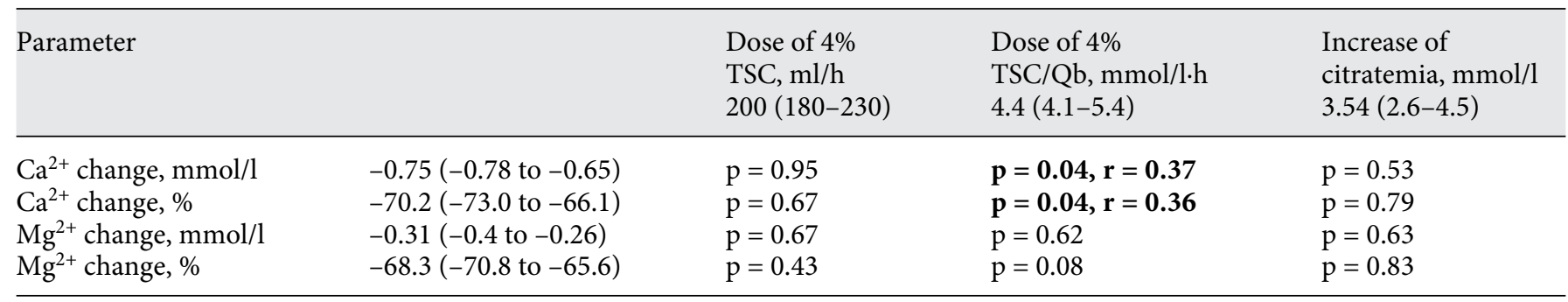

ever, the postfilter $\mathrm{Mg}^{2+}$ significantly correlates with routinely taken postfilter $\mathrm{Ca}^{2+}$. In contrast to $\mathrm{Mg}^{2+}$, the absolute and percentual decreases of $\mathrm{Ca}^{2+}$ correlated to the dose of citrate per $\mathrm{Qb}$. This could be partially due to the confounding effect of magnesium in the dialysate/ substitution fluid, which was calcium free. This study including normomagnesemic patients (table 1) also shows very similar relationship between $\mathrm{Mg}^{\text {tot }}$ and $\mathrm{Mg}^{2+}$ in systemic blood when using citrate anticoagulation compared to this relationship in non-renal failure patients $[20,21]$. The losses of $\mathrm{Mg}^{\text {tot }}$ were in contrast to mild gain of $\mathrm{Ca}^{\text {tot }}$, which is caused by the routine postfilter calcium infusion during RCA compared to the absence of postfilter magnesium substitution. On the other hand, the losses of $\mathrm{Mg}^{\text {tot }}$ were limited by $\mathrm{Mg}$ levels in dialysis and substitution fluid, which was calcium free and were balanced by the routine parenteral magnesium sulfate replenishment included in the institutional RCA protocol. The presence of magnesium in dialysis/ substitution fluid in citrate anticoagulated CRRT is a matter of debate $[8,22]$ because $\mathrm{Mg}$ is also chelated by citrate, which may neutralize a portion of citrate and increase the demand for its infusion to lower $\mathrm{Ca}^{2+}$ postfilter into a desired range. The importance of removing magnesium for reduction of filter clotting is questionable [23], and the eventual reduction of citrate dosage for calcium chelation does not outweigh the risk of hypomagnesemia $[13,20,24,25]$ if $\mathrm{Mg}$ is not replenished properly $[9,17]$.

The study shows that the decreases of $\mathrm{Mg}^{\text {tot }}$ are not sufficiently compensated by the amount of magnesium in dialysis/substitution fluid even with the level of 0.75 $\mathrm{mmol} / \mathrm{l}$. The estimated median loss of magnesium of 22 $\mathrm{mmol} /$ day $(-0.91 \mathrm{mmol} / \mathrm{h})$ may represent a depletion of about $15-20 \%$ of total body pool of magnesium during 1 week of CRRT with RCA. The loss is similar to the Brain's study reporting a median of $-1.09 \mathrm{mmol} / \mathrm{h}$ with $0.5 \mathrm{mmol} / \mathrm{l}$ of magnesium in dialysis/substitution fluid and mildly higher Qeffs [12]. Considering the limited body pool of magnesium, the citrate anticoagulated CRRT may put critically ill patients at risk of hypomagnesemia $[13,24]$. A deficit of $\mathrm{Mg}^{\text {tot }}$ and $\mathrm{Mg}^{2+}$ is related to cardiovascular stability, pulmonary hypertension, resistance to insulin, neuromuscular function as well as to non-recovery of renal function and mortality of patients $[13,20,24-30]$. It is very likely that increasing the amount of magnesium in current dialysis/substitution fluids for RCA may eliminate a need for parenteral magnesium replenishment and contribute to the cost effectiveness of RCA modalities.

Our study suffers from several limitations. First, it is limited to only 1 hour of observations. The calculated daily loss of $\mathrm{Mg}^{\text {tot }}$ is therefore only an estimate, because continuous is not always continuous [31]. We did not correct for filter-down time, which differs between centers and modalities. Estimates of total loss of $\mathrm{Mg}^{\text {tot }}$ may therefore be $10-20 \%$ lower. However, this does not apply much to the RCA, because circuit life with citrate is longer and thus the downtime might be shorter. Second, Qb was limited as part of the RCA protocol, limiting the dosage of $4 \%$ TSC and its side effects [18]. Therefore, the magnesium and calcium losses on filter could be even more significant in higher Qbs and higher citrate dosage. Third, our conclusion should also be tested for CVVH, although clearance of magnesium is similar with diffusive transport (dialysis) as with a convective (filtration) mode if a similar dose (Qeff) is applied, because the sieving coefficient of the molecule is about one in both modalities. Fourth, the calcium fluxes and balances would be different if calcium containing fluid would have been used. There are still units where this modality is applied $[32,33]$ leading to a high dosage of citrate and higher amount of calcium-citrate complexes in effluent. Fifth, the changes of calcium and magnesium might relate to citrate dosages and levels of citrate when analyzing larger cohort of patients. 


\section{Conclusion}

This study shows that postfilter $\mathrm{Mg}^{2+}$ decreases similarly as does $\mathrm{Ca}^{2+}$ under RCA. The postfilter $\mathrm{Mg}^{2+}$ can be predicted from postfilter levels of $\mathrm{Ca}^{2+}$. While calcium is routinely replenished as part of the protocol, the loss of $\mathrm{Mg}^{\text {tot }}$ in citrate CVVHDF is not balanced by the insufficient levels in commercially available dialysis/substitution fluids. $\mathrm{Mg}^{2+}$ is related to $\mathrm{Mg}^{\text {tot }}$ similarly as in non- dialysis patients. Citrate anticoagulation of CRRT may lead to the inapparent depletion of magnesium body pool with resulting organ disorders.

\section{Disclosure Statement} 2012 .

The research was supported by the ESICM Stoutenbeek Award

\section{References}

1 Oudemans-van Straaten HM, Bosman RJ, Koopmans M, van der Voort PH, Wester JP, van der Spoel JI, Dijksman LM, Zandstra DF: Citrate anticoagulation for continuous venovenous hemofiltration. Crit Care Med 2009; 37:545-552.

$2 \mathrm{Wu}$ MY, Hsu YH, Bai CH, Lin YF, Wu CH, Tam KW: Regional citrate versus heparin anticoagulation for continuous renal replacement therapy: a meta-analysis of randomized controlled trials. Am J Kidney Dis 2012;59: 810-818.

3 Zhang Z, Hongying N: Efficacy and safety of regional citrate anticoagulation in critically ill patients undergoing continuous renal replacement therapy. Intensive Care Med 2012; 38:20-28.

4 Hetzel GR, Schmitz M, Wissing H, Ries W, Schott G, Heering PJ, Isgro F, Kribben A, Himmele R, Grabensee B, Rump LC: Regional citrate versus systemic heparin for anticoagulation in critically ill patients on continuous venovenous haemofiltration: a prospective randomized multicentre trial. Nephrol Dial Transplant 2011;26:232-239.

5 Oudemans-van Straaten HM, Kellum JA, Bellomo R: Clinical review: anticoagulation for continuous renal replacement therapy - heparin or citrate? Crit Care 2011;15:202.

6 KDIGO; Acute Kidney Injury Work Group: KDIGO clinical practice guideline for acute kidney injury. Kidney Inter Suppl 2012;2:1138.

7 Swartz R, Pasko D, O’Toole J, Starmann B: Improving the delivery of continuous renal replacement therapy using regional citrate anticoagulation. Clin Nephrol 2004;61:134143.

8 Dorval M, Madore F, Courteau S, Leblanc M: A novel citrate anticoagulation regimen for continuous venovenous hemodiafiltration. Intensive Care Med 2003;29:1186-1189.

9 Morgera S, Haase M, Ruckert M, Krieg H, Kastrup M, Krausch D, Vargas-Hein O, Zuckermann-Becker H, Peters H, Pohlmeier R, Neumayer $\mathrm{HH}$ : Regional citrate anticoagulation in continuous hemodialysis - acid-base and electrolyte balance at an increased dose of dialysis. Nephron Clin Pract 2005;101:c211-c219.
10 Brain M, Parkes S, Fowler P, Robertson I, Brown A: Calcium flux in continuous venovenous haemodiafiltration with heparin and citrate anticoagulation. Crit Care Resusc 2011; 13:72-81.

11 Zakharchenko M, Balik M, Leden P: Citrate anticoagulated continuous haemodiafiltration: focus on ionised magnesium. Intensive Care Med 2011;37:336.

12 Brain $\mathrm{M}$, Anderson M, Parkes S, Fowler P: Magnesium flux during continuous venovenous haemodiafiltration with heparin and citrate anticoagulation. Crit Care Resusc 2012; 14:274-282.

13 Soliman HM, Mercan D, Lobo SS, Melot C, Vincent JL: Development of ionized hypomagnesemia is associated with higher mortality rates. Crit Care Med 2003;31:10821087.

14 Mercan D, Bastin G, Lambermont M, Dupont E: Importance of ionized magnesium measurement for monitoring of citrate-anticoagulated plateletpheresis. Transfusion 1997;37: 418-422.

15 RENAL Replacement Therapy Study Investigators, Bellomo R, Cass A, Cole L, Finfer S, Gallagher M, Lo S, McArthur C, McGuinness S, Myburgh J, Norton R, Scheinkestel C, Su S: Intensity of continuous renal-replacement therapy in critically ill patients. N Engl J Med 2009;361:1627-1638.

16 VA/NIH Acute Renal Failure Trial Network, Palevsky PM, Zhang JH, O'Connor TZ, Chertow GM, Crowley ST, Choudhury D, Finkel K, Kellum JA, Paganini E, Schein RM, Smith MW, Swanson KM, Thompson BT, Vijayan A, Watnick S, Star RA, Peduzzi P: Intensity of renal support in critically ill patients with acute kidney injury. N Engl J Med 2008;359: $7-20$.

17 Morgera S, Scholle C, Voss G, Haase M, Vargas-Hein O, Krausch D, Melzer C, Rosseau $\mathrm{S}$, Zuckermann-Becker $\mathrm{H}$, Neumayer HH: Metabolic complications during regional citrate anticoagulation in continuous venovenous hemodialysis: single-center experience. Nephron Clin Pract 2004;97:c131-c136.

18 Morgera S, Schneider M, Slowinski T, VargasHein O, Zuckermann-Becker H, Peters H,
Kindgen-Milles D, Neumayer HH: A safe citrate anticoagulation protocol with variable treatment efficacy and excellent control of the acid-base status. Crit Care Med 2009;37: 2018-2024.

19 Relton S, Greenberg A, Palevsky PM: Dialysate and blood flow dependence of diffusive solute clearance during CVVHD. ASAIO J 1992;38:M691-M696.

20 Escuela MP, Guerra M, Anon JM, MartinezVizcaino V, Zapatero MD, Garcia-Jalon A, Celaya S: Total and ionized serum magnesium in critically ill patients. Intensive Care Med 2005;31:151-156.

21 Huijgen HJ, Soesan M, Sanders R, Mairuhu WM, Kesecioglu J, Sanders GT: Magnesium levels in critically ill patients. What should we measure? Am J Clin Pathol 2000;114:688695.

22 Janssen MJ HP, Bouman AA, Oe PL, van der Meulen J: Citrate anticoagulation and divalent cations in hemodialysis. Blood Purif 1994;12:308-316.

23 Ames WA, McDonnell N, Potter D: The effect of ionised magnesium on coagulation using thromboelastography. Anaesthesia 1999;54: 999-1001.

24 Ismail Y, Ismail AA, Ismail AA: The underestimated problem of using serum magnesium measurements to exclude magnesium deficiency in adults; a health warning is needed for 'normal' results. Clin Chem Lab Med 2010;48:323-327.

25 Tong GM, Rude RK: Magnesium deficiency in critical illness. J Intensive Care Med 2005. 20:3-17.

26 Touvier M, Lioret S, Vanrullen I, Boclé JC, Boutron-Ruault MC, Berta JL, Volatier JL: Vitamin and mineral inadequacy in the French population: estimation and application for the optimization of food fortification. Int J Vitam Nutr Res 2006;76:343-351.

27 Dittrich S, Germanakis J, Dähnert I, Stiller B, Dittrich H, Vogel M, Lange PE: Randomised trial on the influence of continuous magnesium infusion on arrhythmias following cardiopulmonary bypass surgery for congenital heart disease. Intensive Care Med 2003;29: 1141-1144. 
28 Lima Mde L CT, Rodrigues LE, Bomfim O, Melo J, Correia R, Porto M, Cedro A, Vicente E: Serum and intracellular magnesium deficiency in patients with metabolic syndrome evidences for its relation to insulin resistance. Diabetes Res Clin Pract 2009;83:257-262.

29 Alves SC, Tomasi CD, Constantino L, Giombelli V, Candal R, Bristot Mde L, Topanotti MF, Burdmann EA, Dal-Pizzol F, Fraga CM, Ritter C: Hypomagnesemia as a risk factor for the non-recovery of the renal function in critically ill patients with acute kidney injury. Nephrol Dial Transplant 2013;28:910-916.
30 João Matias P, Azevedo A, Laranjinha I, Navarro $\mathrm{D}$, Mendes $\mathrm{M}$, Ferreira $\mathrm{C}$, Amaral $\mathrm{T}$, Jorge C, Aires I, Gil C, Ferreira A: Lower serum magnesium is associated with cardiovascular risk factors and mortality in haemodialysis patients. Blood Purif 2014;38:244252.

31 Uchino S, Fealy N, Baldwin I, Morimatsu H, Bellomo R: Continuous is not continuous: the incidence and impact of circuit 'down-time' on uraemic control during continuous venovenous haemofiltration. Intensive Care Med 2003;29:575-578.
32 Gupta M, Wadhwa NK, Bukovsky R: Regional citrate anticoagulation for continuous venovenous hemodiafiltration using calciumcontaining dialysate. Am J Kidney Dis 2004; 43:67-73.

33 Ong SC, Wille KM, Speer R, Tolwani AJ: A continuous veno-venous hemofiltration protocol with anticoagulant citrate dextrose formula $\mathrm{A}$ and a calcium-containing replacement fluid. Int J Artif Organs 2014;37:499502 . 